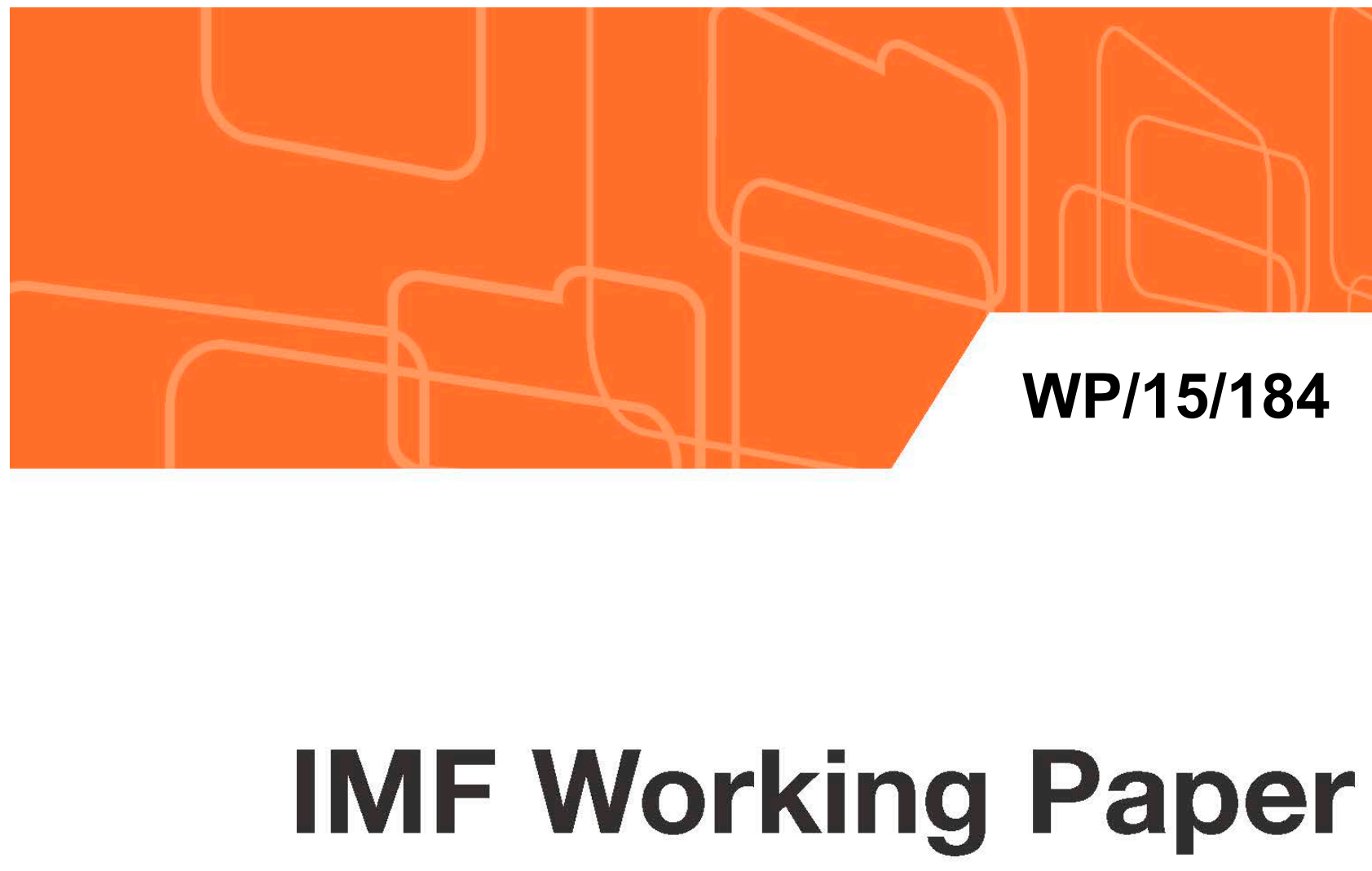

\title{
Integrated Ownership and Control in the GCC Corporate Sector
}

by André Oliveira Santos

IMF Working Papers describe research in progress by the author(s) and are published to elicit comments and to encourage debate. The views expressed in IMF Working Papers are those of the author(s) and do not necessarily represent the views of the IMF, its Executive Board, or IMF management.

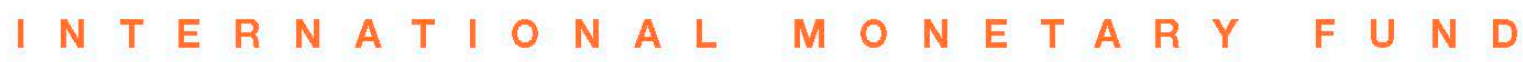




\title{
IMF Working Paper
}

\author{
Middle East and Central Asia Department \\ Integrated Ownership and Control in the GCC Corporate Sector \\ Prepared by André Oliveira Santos \\ Authorized for distribution by Timothy Callen
}

August 2015

IMF Working Papers describe research in progress by the author(s) and are published to elicit comments and to encourage debate. The views expressed in IMF Working Papers are those of the author(s) and do not necessarily represent the views of the IMF, its Executive Board, or IMF management.

\begin{abstract}
The objective of the paper is to assess ownership and control links in the GCC corporate sector. The analysis focuses on the integrated ownership and network arising from ownership data available in Bloomberg and GCC stock exchanges. The paper finds that ownership is concentrated in GCC public sector institutions, holding companies, financial institutions, and family groups. The paper then considers the effect of different definitions of control on the distribution of consolidated debt. Debt concentration is maximized when the wedge between ownership and control is the largest. This is the case when the largest shareholder has at least 5 percent of total shares as defined in Zingales (1994).
\end{abstract}

JEL Classification Numbers: G34, G38

Keywords: GCC countries, network analysis, integreated ownership, concentration

Author's E-Mail Address: Asantos2@imf.org 


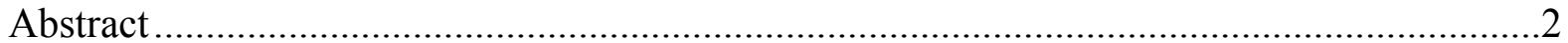

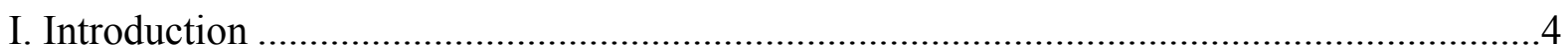

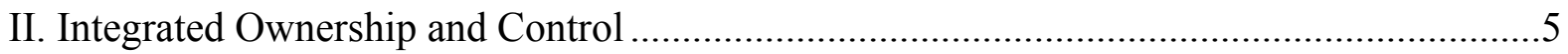

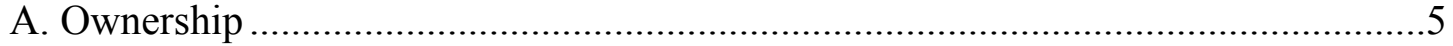

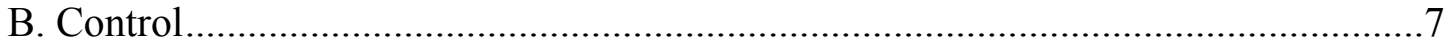

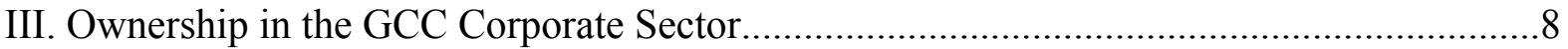

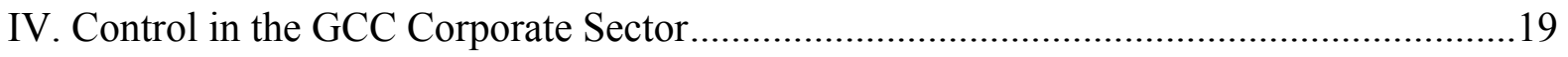

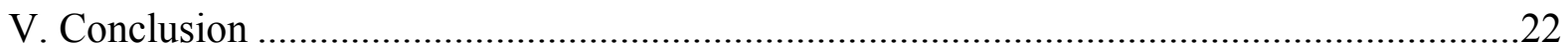

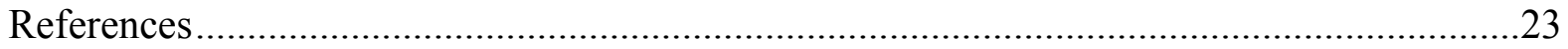

Tables

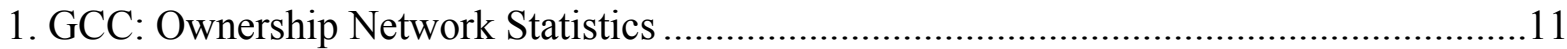

2. Largest Shareholders in Selected Countries .............................................................. 12

Figures

1. Bahrain: Corporate Ownership Network ..................................................................... 13

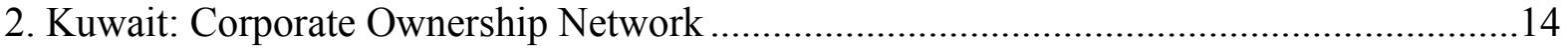

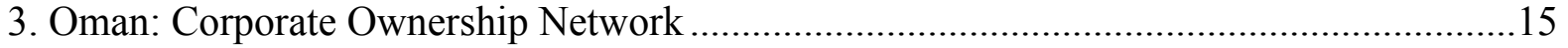

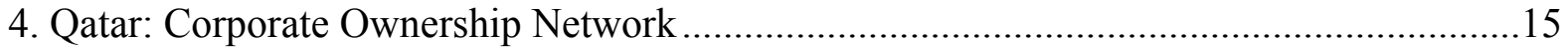

5. Saudi Arabia: Corporate Ownership Network ...............................................................16

6. UAE: Corporate Ownership Network.................................................................. 17

7. GCC: Concentration in Ownership Networks, End-2013 .............................................. 18

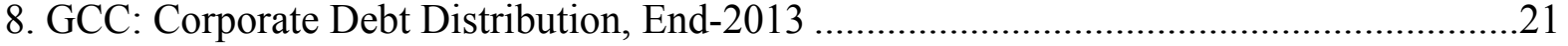




\section{INTRODUCTION ${ }^{1}$}

The GCC corporate, financial, and public sectors are characterized by a high degree of interconnectedness. Ownership links in the corporate, financial, and public sectors imply close connections among industrial, commercial, and financial groups, and sovereigns. Large industrial and commercial groups have ownership stakes in banks while GCC governmentsthrough different government agencies - have stakes in several groups. Financial groups are also shareholders in banks, industrial, and commercial groups. As a consequence, GCC banks may have exposures to a group of counterparties with dependencies that imply they are all likely to fail simultaneously.

The Basel Committee on Banking Supervision, in April 2014, published standards that set out a supervisory framework for measuring and controlling large exposures, which will take effect from 1 January 2019. Under the framework, large exposures were defined as the sum of all exposures to a counterparty or to a group of connected counterparties equal to or above 10 percent of the capital base (Tier 1 capital). ${ }^{2}$ The new Basel framework has further defined connected counterparties as a group of counterparties linked by a control relationship (either direct or indirect) or an economic interdependence. In this case, the exposures to all connected counterparties should be considered as a large single exposure for reporting and compliance purposes. A key lesson from the financial crisis is that it is important for banks to consistently measure, aggregate and control exposures to these counterparties.

Network analysis is a useful way to visualize connected counterparties through direct and indirect ownership and control links. Directed ownership networks are a system of links among shareholders and corporates organized in a way that visual inspection and analysis are made easier. Shareholders have portfolios consisting of direct investments in corporates. They can also have indirect stakes in corporates that are part of investments by corporates in which they hold shares. In this case, integrated ownership and control are determined by the direct and indirect links in the ownership network.

The objective of the paper is to assess ownership and control links in GCC countries and identify connected counterparties and their consolidated debt. The analysis focuses on the integrated ownership and network arising from ownership data available in Bloomberg and GCC stock exchanges. The paper also analyzes the ownership concentration in GCC countries and identifies the key stakeholders. The paper then considers the effect of different definitions of control on the distribution of consolidated debt. The literature on corporate governance has defined share ownership thresholds associated with corporate control. These

\footnotetext{
${ }^{1}$ This research was prepared as a background paper for the IMF publication on "Assessing Concentration Risk in GCC Banks." The author is grateful for the guidance and comments provided by Tim Callen, Prasad Ananthakrishnan, Adrian Alter, Hesham Fahad Alogel, Harald Finger, and seminar participants in the MCD Discussion Forum. The author is also grateful to Diana Kargbo-Sical and Juan Carlos Flores for their editorial and research assistance. Any remaining errors are solely the author's responsibility.

${ }^{2}$ Further, the Basel committee has also set a limit of 25 percent of the bank's capital base for the largest exposures and has recommended that banks should report to the supervisor exposures equal to or greater than 10 percent of the capital base, all the exemptions granted, and the 20 largest exposures irrespective of the value of these exposures relative to the capital base.
} 
ownership thresholds are used to identify connected counterparties - involving entities under the direct and indirect control of shareholders - and their consolidated debt.

The paper contributes to the literature in several ways. First, the paper shows that the corporate ownership is strongly concentrated in the GCC countries. Public sector institutions are at the center of GCC corporate ownership networks, but holding companies, financial institutions, and family groups are also important. As cross-shareholdings are not widespread, GCC ownership networks have hierarchical structures with multiple lines of command. Second, the paper identifies connected counterparties and their consolidated debt. The paper considers the effect of different definitions of control on the distribution of consolidated debt. Debt concentration is then the highest when the wedge between ownership and control is the largest, as can be the case as in the Zingales (1994) definition of control in which the largest shareholders should hold at least 5 percent of total shares in a company.

The rest of the paper is organized in the following manner. Section II discusses the concepts of integrated ownership and corporate control. Section III analyzes ownership networks in GCC countries. Section IV then discusses the impact of different definitions of control on the consolidated debt of connected counterparties. The final section discusses the main findings in the paper.

\section{INTEGRATED OWNERSHIP AND CONTROL}

\section{A. Ownership}

The analysis of integrated ownership has relied on the input-output theory to identify direct and indirect links among shareholders and corporates. ${ }^{3}$ Ellerman (1991) and others used the input-output theory to analyze cross-ownership in corporates and obtain an integrated (or external) ownership matrix from data on direct ownership by shareholders. He proposed that any corporate flow or stock can be adjusted by the integrated (or external) ownership matrix to derive its external value.

Chapelle and Szafarz $(2002,2005)$ have extended Ellerman (1991) to analyze corporate control in pyramidal structures. They used the input-output theory to obtain integrated ownership and control in pyramidal structures with cross ownerships in Belgium corporates. Gutiérrez, Pombo, and Taborda (2005) and Gutiérrez and Pombo (2007) analyzed the separation between ownership and control in Colombian corporates using an integrated ownership matrix. They found that voting rights are greater than cash flow rights due to indirect and cross ownership.

The model in Ellerman (1991) and others is useful to analyze integrated ownership. Let $\boldsymbol{A}$ be a $n$-squared matrix where element $\boldsymbol{a}_{i j}$ represents the percentage of the equity that shareholder $\boldsymbol{i}$ holds in corporate $\boldsymbol{j}$. Matrix $\boldsymbol{A}$ then consists of the direct ownership links between shareholders and corporates and is also called the adjacency matrix in network analysis.

\footnotetext{
${ }^{3}$ Glattfelder (2013) summarized the literature on integrated ownership.
} 
Ultimate shareholders have columns with zeros and rows with the percentages of total shares held in the different corporates. Corporates have columns with the percentages of total shares held by the different shareholders and rows with zeros if they have no investment in other corporates. However, in the case of cross-ownership links, corporates would have rows with percentages of total shares held in other corporates.

Let also the $n$-squared matrix $\boldsymbol{Y}$ represent the integrated ownership matrix with direct and indirect ownership links. That is, element $y_{i j}$ is the percentage of total shares held directly and indirectly by shareholder $\boldsymbol{i}$ in corporate $\boldsymbol{j}$ :

$$
Y=A+A^{2}+A^{3}+\ldots+A^{N}
$$

where the power matrix $\boldsymbol{A}^{i}$ provides the $i$-th indirect ownership links associated with the ultimate shareholders. ${ }^{4}$ If the number of links $N$ tends to infinity, the power series would tend to the limit given by:

$$
\lim _{N \rightarrow \infty} \sum_{i=0}^{N} A^{i}=A(I-A)^{-1}
$$

This is also the solution to the $\boldsymbol{Y}$ matrix that includes both the direct and indirect linkages and consists of a sum of two terms:

$$
Y=A+A Y,
$$

where the first term is the n-squared matrix $\boldsymbol{A}$ with the direct ownership links while the second term is the n-squared product matrix $\boldsymbol{A} \boldsymbol{Y}$ representing the indirect ownership links associated with the direct investment in corporates.

The solution to this linear equation is:

$$
Y=A(I-A)^{-1}
$$

Matrix $\boldsymbol{Y}$ can, however, can have double-counting elements associated with cross-ownership shares. The double counting can be overcome by an adjustment proposed in Ellerman (1991) and others. Let $\boldsymbol{V}$ denote the adjusted $n$-squared integrated ownership matrix with direct and indirect ownership links. If the adjustment is proportional to the percentage of shares held by outsiders and not included in the direct ownership matrix $\boldsymbol{A}$, then matrix $V$ can be written as:

$$
V=\operatorname{Diag}(I-\bar{A}) A(I-A)^{-1},
$$

where the elements in the n-squared diagonal matrix $\bar{A}=\left[\bar{a}_{j j}\right]$ are the sum of all shares in corporate $j$ held by shareholders and corporates in the network:

\footnotetext{
${ }^{4}$ See Kogut and Walker (2001), appendix A.
} 


$$
\bar{a}_{j j}=\sum_{i=1}^{n} a_{i j} .
$$

The diagonal matrix $\operatorname{Diag}(\boldsymbol{I}-\overline{\boldsymbol{A}})$ then includes shares held by outsiders that are not in the direct ownership matrix $\boldsymbol{A}$.

\section{B. Control}

From a supervisory and regulatory perspective, an analysis of effective control over corporates should uncover the control links behind connected counterparties. This is important because the failure of one counterparty can lead to the failure of other counterparties and impair bank capital if bank exposures are large and not consolidated.

However, control over corporates is difficult to assess and quantify. The one-share-one-vote rule implies that shareholders with large stakes are associated with the right to appoint board members and control firms. If $\boldsymbol{C}$ denotes the matrix of direct effective control, its elements $\boldsymbol{c}_{i j}$ under the one-share-one-vote rule are proportional to shareholders' ownership $\boldsymbol{a}_{i j}$ :

$$
c_{i j}=\left\{\begin{array}{l}
a_{i j} / \sum_{i=1}^{n} a_{i j} \text { iff } \sum_{i=1}^{n} a_{i j}>0 ; \\
0, \text { otherwise. }
\end{array}\right.
$$

Zingales $(1994,1995)$ suggested a share threshold for corporate control. He assumed that control is exercised by the largest shareholder with at least 5 percent of total shares. In this case, the elements in matrix $\boldsymbol{C}$ under Zingales $(1994,1995)$ are given by:

$$
c_{i j}=\left\{\begin{array}{l}
1 \text { iff } a_{i j}=\max \left(a_{1 j}, \ldots, a_{n j}\right) \text { and } a_{i j}>5 \text { percent for corporate } j \\
0, \text { otherwise. }
\end{array}\right.
$$

La Porta, Lopez-de-Silanes, and Sheleifer (1999) proposed that the largest shareholder should have at least 20 percent of total shares to exert control. If the largest shareholders have less than 20 percent of total shares as a block, the corporate is then considered widely held by the public. The specification of the elements in matrix $\boldsymbol{C}$ under La Porta, Lopez-deSilanes, and Sheleifer (1999) is then given by:

$$
c_{i j}=\left\{\begin{array}{l}
1 \text { iff } a_{i j}=\max \left(a_{1 j}, \ldots, a_{n j}\right) \text { and } a_{i j}>20 \text { percent for corporate } j \\
0, \text { otherwise. }
\end{array}\right.
$$

Chapelle and Szafarz $(2002,2005)$ suggested the 50 percent majority threshold. This is associated with the voting power in shareholders' meetings needed to impose any decision. If the largest shareholders do not have more than 50 percent of total shares, then they share control in proportion to their shares. The elements in matrix $\mathrm{C}$ under Chapelle and Szafarz (2002, 2005) are given by: 


$$
c_{i j}=\left\{\begin{array}{l}
1 \text { iff } a_{i j} \geq 50 \text { percent for corporate } j ; \\
0 \text { if } \exists k \neq i \text { such that } a_{k j} \geq 50 \text { percent for corporate } j \\
a_{i j}, \text { otherwise. }
\end{array}\right.
$$

A variant of matrix C in Chapelle and Szafarz $(2002,2005)$ would still require the 50 percent majority threshold. However, control would proportional to the shares if the largest shareholders do not hold more than 50 percent of total shares in corporate $j$ :

$$
c_{i j}=\left\{\begin{array}{l}
1 \text { iff } a_{i j} \geq 50 \text { percent for corporate } j \\
0 \text { if } \exists k \neq i \text { such that } a_{k j} \geq 50 \text { percent for corporate } j \\
a_{i j} / \sum_{i=1}^{n} a_{i j} \text { iff } a_{i j}<50 \text { percent; } \\
0, \text { otherwise. }
\end{array}\right.
$$

Similar to the adjusted integrated matrix $\boldsymbol{V}$ of direct and indirect ownership links, the equivalent adjusted matrix $\boldsymbol{T}$ of direct and indirect effective control can then be written as:

$$
T=\operatorname{Diag}(I-\bar{C}) C(I-C)^{-1} .
$$

Let $\boldsymbol{D}$ denote an $n$-dimension vector consisting of shareholder and corporate debt. Let also $\boldsymbol{G}$ be an n-squared conditional identity matrix in which the diagonal element $\boldsymbol{g}_{j j}$ is conditional on whether column $\boldsymbol{j}$ in matrix $\mathrm{T}$ is associated with a corporate or an ultimate shareholder:

$$
g_{j j}=\left\{\begin{array}{l}
1 \text { iff } \sum_{i=1}^{n} t_{i j}=0, \text { in which case column } \boldsymbol{j} \text { is an ultimate shareholder; } \\
0 \text { iff } \sum_{i=1}^{n} t_{i j}>0, \text { in which case column } \boldsymbol{j} \text { is a corporate. }
\end{array}\right.
$$

The $n$-dimension vector $\boldsymbol{W}$ of connected counterparties' consolidated debt is obtained by:

$$
W=(T+G) D .
$$

The first term $\boldsymbol{T}$ on the right-hand adds the corporate debt under the direct and indirect control of shareholders to the ultimate shareholder debt represented by the second term $\boldsymbol{G}$.

\section{OWNERSHIP IN THE GCC CORPORATE SECTOR}

Ownership data from Bloomberg based on disclosures by GCC stock exchanges and private sources are useful to describe ownership links in the corporate sector. GCC stock exchanges provide information on domestic and foreign shareholders with more than 5 percent of total shares in publicly listed companies. GCC stock exchanges list names and the percentage of shares directly held by shareholders. In addition to stock exchanges, some privately-owned corporates also disclose information on their ownership structure. This information on 
shareholders in publicly listed and privately-owned corporates can then be used to assess the ownership structure of the corporate sector, its interconnectedness, and its control links.

Network analysis is a convenient way to visualize and analyze the ownership links in the corporate sector. The direct ownership matrix A (the adjacency matrix) in equation 1 in section II.B contains information on shareholders and corporates displayed in rows and columns. In a network graph, the same information is shown by a set of nodes and links. Nodes represent either shareholders or corporates while the arrows are the ownership links (or edges). Shareholders are located on the tail side of the arrow while corporates are placed on the head side. The thickness of the arrows is proportional to the percentage of shares held by shareholders. For example, the 29 percent ownership stake of the Dubai government in Emaar Properties would be represented by a scaled arrow-proportional to the 29 percent share - starting at the node named Dubai government and pointing to the node named Emaar Properties. Linking shareholders and corporates in successive layers, network graphs then provide a picture of the direct and indirect ownership links. While shareholder portfolios consist of direct shares in corporates in the first layer in a pyramid, indirect ownership in corporates is given by the lower layers. In this case, ultimate ownership and control is determined by the direct and indirect links in the ownership network.

However, the analysis of interconnectedness in the corporate sector based on information available in Bloomberg, GCC stock exchanges, and private sources has important gaps. First, a large number of privately owned corporates with no disclosed ownership information is left unaccounted. Second, ownership information on publicly listed companies might not contain details on the ultimate shareholder. Holding companies, for instance, are used by ultimate shareholders to manage corporates. If their shares are not publicly listed in stock exchanges, then ultimate shareholders cannot be identified. Finally, the links between corporates and shareholders rely on consistent records. The imprecise registration of shareholder and corporate add uncertainty to the network. For instance, in the GCC stock exchange records, the Arabic article Al can be part of a name. Some ownership records include it while others do not. The search for interconnected shareholders and corporates then requires text mining to reduce names to their roots and compare them.

Ownership in GCC countries is concentrated in public sector institutions, holding companies, financial institutions, and family groups. Figures 1-6 provide ownership links among domestic shareholders and corporates in GCC countries based on disclosures by GCC stock exchange and private sources. The emphasis on domestic shareholders reflects not only the focus of the paper on domestic links among shareholders and corporates but also ownership restrictions in GCC countries where foreign majority ownership is not encouraged: ${ }^{5}$

\footnotetext{
${ }^{5}$ See International Monetary Fund (2014). Most countries do not impose ownership restrictions on GCC nationals. Most countries also allow exceptions in the foreign ownership restrictions for investments in specific sectors.
} 
- $\quad$ Bahrain: Subject to government approval;

- Kuwait: Foreign investors can own up to 49 percent of Kuwaiti companies;

- Oman: Foreign ownership of shares in Omani companies is limited to 70 percent;

- Qatar: Foreign investors cant own up to 49 percent of total shares;

- $\quad$ Saudi Arabia: Direct ownership of shares by Qualified Foreign Investors up to 49 percent has been allowed since June 15,$2015 ;{ }^{6}$

- $\quad$ United Arab Emirates: Foreign investors are limited to 49 percent of total shares.

Even though table 1 indicates that the average number of links (the average degree) in GCC ownership networks is about one-implying that the average investor owns only one company (a low ownership concentration) - there are few nodes with a high number of links (degree). These include not only public sector institutions, which are at the center of the networks with the highest number of links (or degree), but also holding companies, financial institutions, and family groups with a lower number of ownership links (or degree). This is consistent with Figure 7 where the Lorenz curve with the accumulated percentage of shareholders associated with a number of nodes and the implied Gini coefficient portray strong ownership concentration in GCC countries. ${ }^{7}$ In addition, Table 2 contains statistics on block of shareholders holding at least 5 percent of total shares and indicates that ownership in GCC countries is concentrated. The median of shareholder blocks holds more than 26 percent of total shares in GCC countries. This is consistent with findings in Alves (2010) that also describes corporate ownership in selected advanced and emerging market countries as concentrated in few shareholders. Generally, ownership in GCC countries is more concentrated than most selected countries.

\footnotetext{
${ }^{6}$ For more details on individual limits, see Kingdom of Saudi Arabia Capital Market Authority (2015).

${ }^{7}$ Kunegis and Preusse (2012) proposed the use of the Lorenz curve and the associated Gini coefficient as a measure to quantify concentration in networks. The Gini coefficient is the ratio of the area between the 45 degree line and the curve to the area in the lower triangle under the 45 degree line. Coefficients close to one imply extreme ownership concentration while coefficients close to zero are an indication of no ownership concentration.
} 
Table 1. GCC: Ownership Network Statistics

\begin{tabular}{lcccccccc}
\hline & $\begin{array}{c}\text { Number of } \\
\text { Nodes }\end{array}$ & $\begin{array}{c}\text { Number of } \\
\text { Links }\end{array}$ & $\begin{array}{c}\text { Average } \\
\text { Degree 1/ }\end{array}$ & $\begin{array}{c}\text { Average } \\
\text { Distance } \\
\text { Avg. Path } \\
\text { Length) 2/ }\end{array}$ & $\begin{array}{c}\text { Krackhardt } \\
\text { Hierarchy } \\
\text { Score 3/ }\end{array}$ & $\begin{array}{c}\text { Krackhardt } \\
\text { Connectedness } \\
\text { Score 4/ }\end{array}$ & $\begin{array}{c}\text { Krackhardt } \\
\text { Efficiency } \\
\text { Score 5/ }\end{array}$ & $\begin{array}{c}\text { Krackhardt } \\
\text { LUBness } \\
\text { Score 6/ }\end{array}$ \\
\hline Bahrain & 114 & 109 & 1.0 & 1.4 & 1.0 & 0.4 & 1.0 & 0.1 \\
Kuwait & 466 & 466 & 1.0 & 1.4 & 1.0 & 0.4 & 1.0 & 0.0 \\
Oman & 332 & 321 & 1.0 & 1.4 & 1.0 & 0.5 & 1.0 & 0.0 \\
Qatar & 31 & 22 & 0.7 & 1.0 & 1.0 & 0.1 & 1.2 & 0.3 \\
Saudi Arabia & 349 & 311 & 0.9 & 1.1 & 1.0 & 0.1 & 1.0 & 0.1 \\
United Arab Emirates & 347 & 312 & 0.9 & 1.1 & 1.0 & 0.1 & NA & NA \\
\hline
\end{tabular}

Source: Staff calculations.

$1 /$ Average degree is the average number of links per node.

2/ Distance is the number of links in a shortest path connecting two nodes.

$3 /$ Krackhardt hierarchy score is a measure of the extent that paths are reciprocated. Values closer to 1 (to zero) indicate no reciprocity (reciprocity).

4/ Krackhardt connectedness score is a measure of the extent that the network is just one weak structure. Values closer to 1 (to zero) indicate nodes are fully connected (weakly connected).

$5 /$ Krackhard efficiency is a measure of the extent that the number of links approaches the minimum necessary to prevent the network from fragmenting into two distinct pieces. Values close to 1 (to zero) indicate an optimal (suboptimal) number of links between nodes.

6/ Least Upper Boundedness (LUB). This is a measure of the entent of the unity-of-command in a network. Values closer to 1 (to zero)

indicate only 1 (more than one lines) line of command.

As a result of few cross-ownership links in which two or more companies reinforce their business ties by owning shares in each other, GCC ownership networks are similar to hierarchical structures with multiple lines of command. Even though Table 1 indicates that GCC networks are weakly-connected structures overall given the low (close to zero) Krackhard connected scores, Figures 1-6 display strongly connected networks around investors with a high number of links, especially around public sector institutions, holding companies, financial institutions, and family groups. ${ }^{8,9}$ Table 1 also implies that crossownerships in GCC networks are non-existent, as measured by the high (close to unity) Krackhard hierarchy scores. Instead, GCC ownership networks have hierarchical structures with lines of command spread among different investors, as measured by the low (close to zero) Krackhard least upper boundedness score. As a network of investors and companies, this is more than expected. In addition, some shareholders also dispose high eccentricity, which is the distance from a node to the farthest one, providing an indication of consecutive ownership and control links spreading from the top to the bottom nodes. However, a few corporates such as the Investment Corporation of Dubai have higher inner and outer links (or degrees) and play a role as hubs.

\footnotetext{
${ }^{8}$ See Krackhardt (1994).

${ }^{9}$ The networks were plotted with the open-source Gephi software. See Bastian, Heymann, and Jacomy (2009).
} 


\begin{tabular}{|c|c|c|c|c|}
\hline \multicolumn{5}{|c|}{ Table 2. Largest Shareholders in Selected Countries } \\
\hline Country & Median Block & Min Block & Max Block & $\begin{array}{c}\text { Average Block by } \\
\text { Firm }\end{array}$ \\
\hline Australia & 7.2 & 5.4 & 50.2 & 9.9 \\
\hline Canada & 67.9 & 5.0 & 78.0 & 21.7 \\
\hline Chile & 19.6 & 5.0 & 83.9 & 63.3 \\
\hline France & 22.6 & 5.0 & 87.3 & 21.5 \\
\hline Germany & 17.7 & 5.8 & 99.1 & 23.6 \\
\hline Hong Kong & 30.0 & 5.0 & 84.6 & 56.9 \\
\hline India & 15.6 & 5.1 & 89.5 & 45.8 \\
\hline Indonesia & 50.5 & 5.1 & 99.1 & 62.9 \\
\hline Malaysia & 14.8 & 5.2 & 64.6 & 57.6 \\
\hline New Zealand & 12.7 & 5.0 & 83.5 & 48.4 \\
\hline Norway & 16.6 & 5.0 & 79.7 & 47.2 \\
\hline Singapore & 15.2 & 5.0 & 82.3 & 41.1 \\
\hline South Africa & 12.7 & 5.3 & 74.5 & 38.1 \\
\hline South Korea & 8.7 & 5.0 & 78.0 & 38.2 \\
\hline Turkey & 24.6 & 5.0 & 93.3 & 67.9 \\
\hline UK & 17.6 & 5.6 & 33.1 & 7.3 \\
\hline USA & 26.9 & 10.6 & 40.7 & 7.2 \\
\hline \multicolumn{5}{|l|}{ GCC } \\
\hline Bahrain & 43.9 & 5.7 & 90.2 & 41.7 \\
\hline Kuwait & 44.3 & 5.6 & 95.8 & 46.0 \\
\hline Oman & 55.0 & 10.2 & 98.1 & 53.0 \\
\hline Qatar & 41.0 & 8.3 & 64.2 & 40.0 \\
\hline Saudi Arabia & 26.2 & 5.0 & 95.0 & 31.7 \\
\hline United Arab Emirates & 47.1 & 5.0 & 99.9 & 47.4 \\
\hline \multicolumn{5}{|c|}{$\begin{array}{l}\text { Source: Alves (2010) and Sfaff estimates. } \\
1 / \text { Blocks of shareholders are defined as } f \text { the sum of all investors holding more than } 5 \text { percent of total } \\
\text { shares in each company. So, the median, minimum, maximum, and mean blocks are statistics compiled } \\
\text { for blocks of shareholders for all companies. }\end{array}$} \\
\hline
\end{tabular}

In sum, the analysis suggests three main conclusions about GCC corporate ownership (keeping in mind the caveats discussed at the top of page 9): (i) corporate ownership is strongly concentrated in the GCC countries; (ii) public sector institutions (such as the Social Insurance Organization in Bahrain; the Kuwait Investment Authority; the government and ministry of finance in Oman; the Qatar Investment Authority and Qatar Holdings; the General Organization of Social Insurance, the General Retirement Organization, and the Public Investment Fund in Saudi Arabia; the Dubai government, Mubadala Development Company, and Sharjah Asset Management in the United Arab Emirates) are at the center of GCC corporate ownership networks, but holding companies (such as Mumtalakat Holding in Bahrain; Dholfar International Development and Investment Holding Company in Oman; El 
Sharq Holdings, Gembal Holdings, and National Industries Group Holdings in Kuwait; Masik Holding Company and Saudi Basic Industries Corporation in Saudi Arabia), financial institutions (National Bank of Bahrain and Kuwait Finance House), and family groups (Abdul Qadir and Sons Company in Saudi Arabia) are also important; and (iii) crossshareholdings are not widespread, rather ownership networks have hierarchical structures with multiple lines of command.

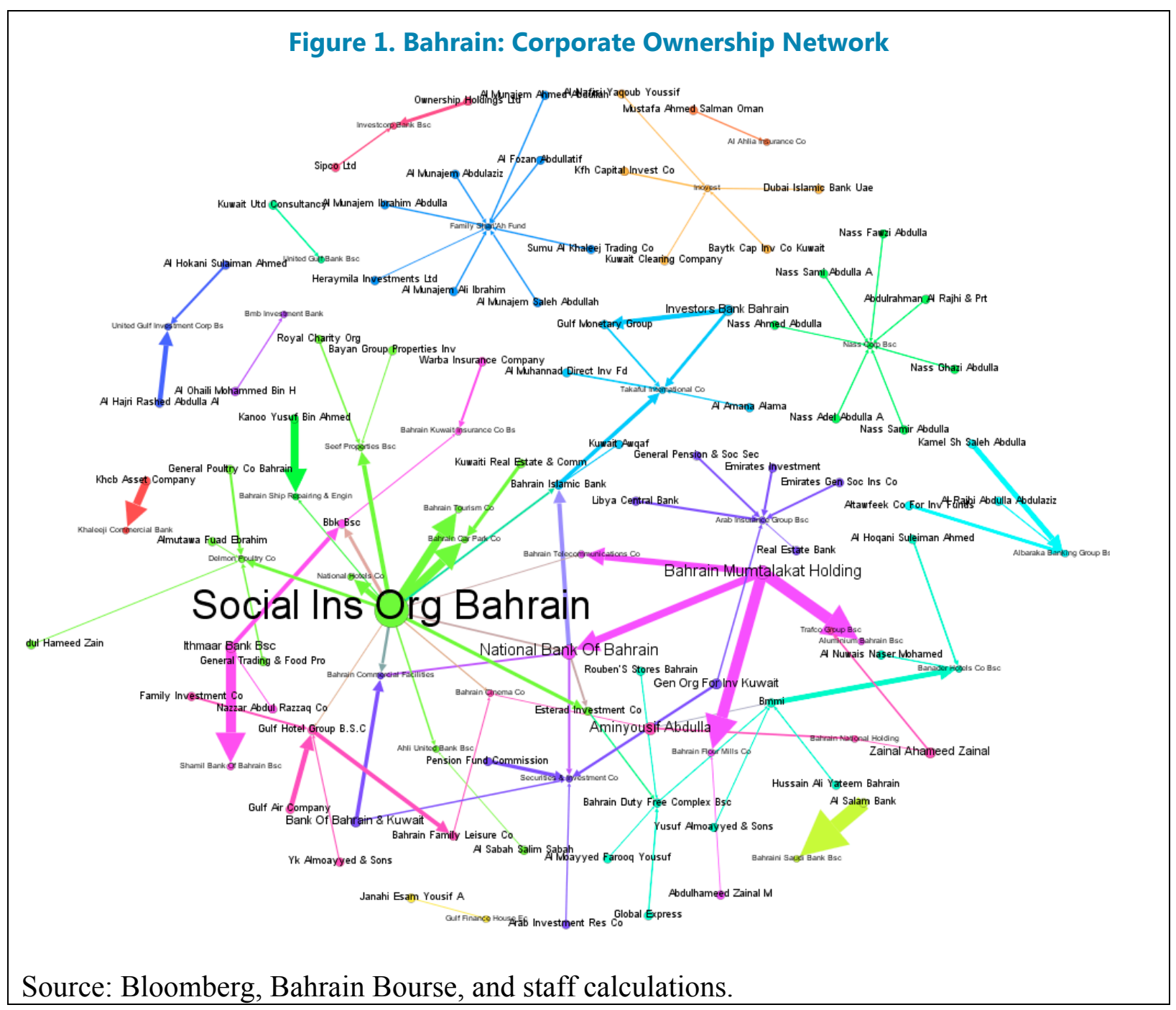




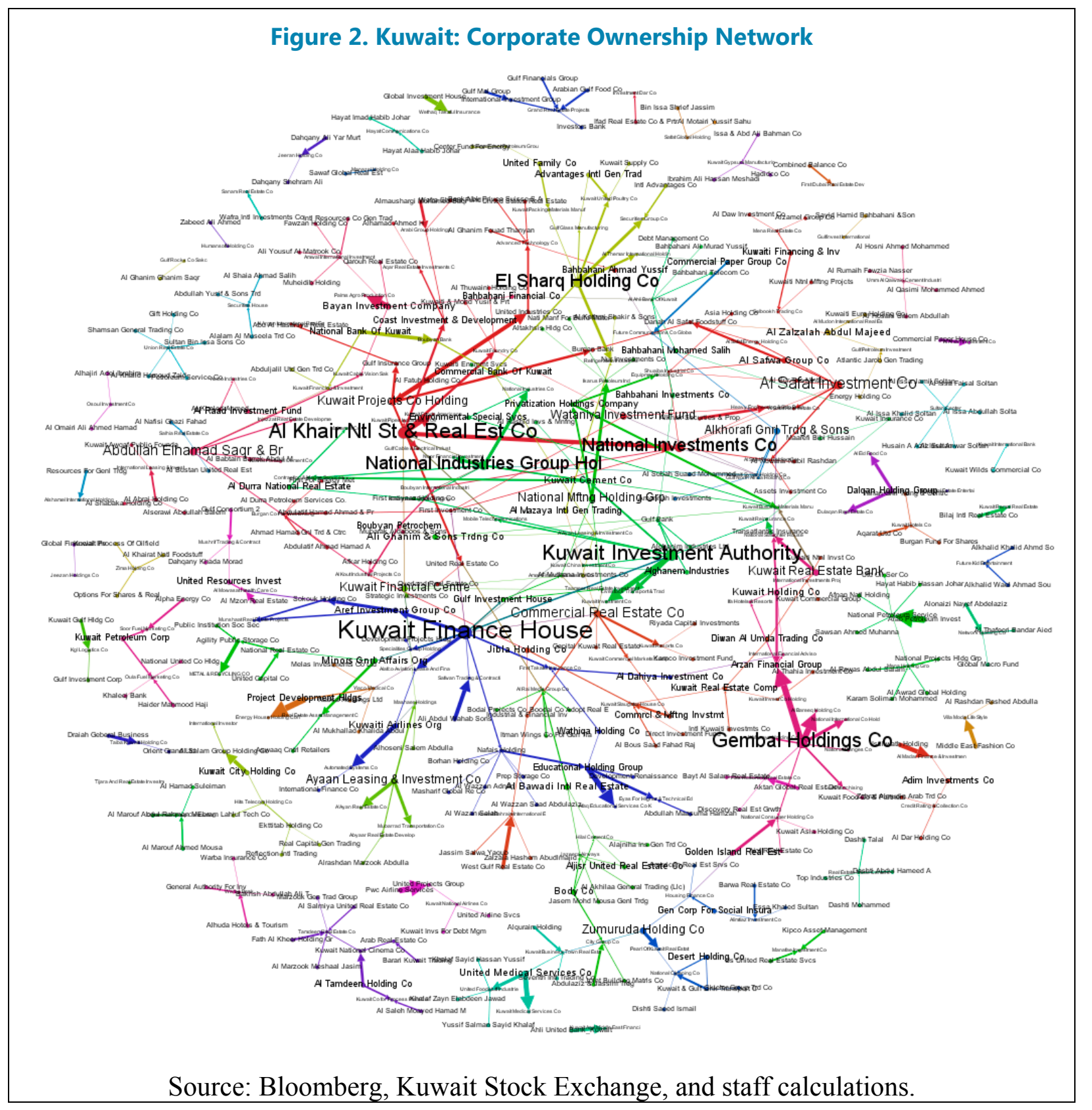


Figure 3. Oman: Corporate Ownership Network

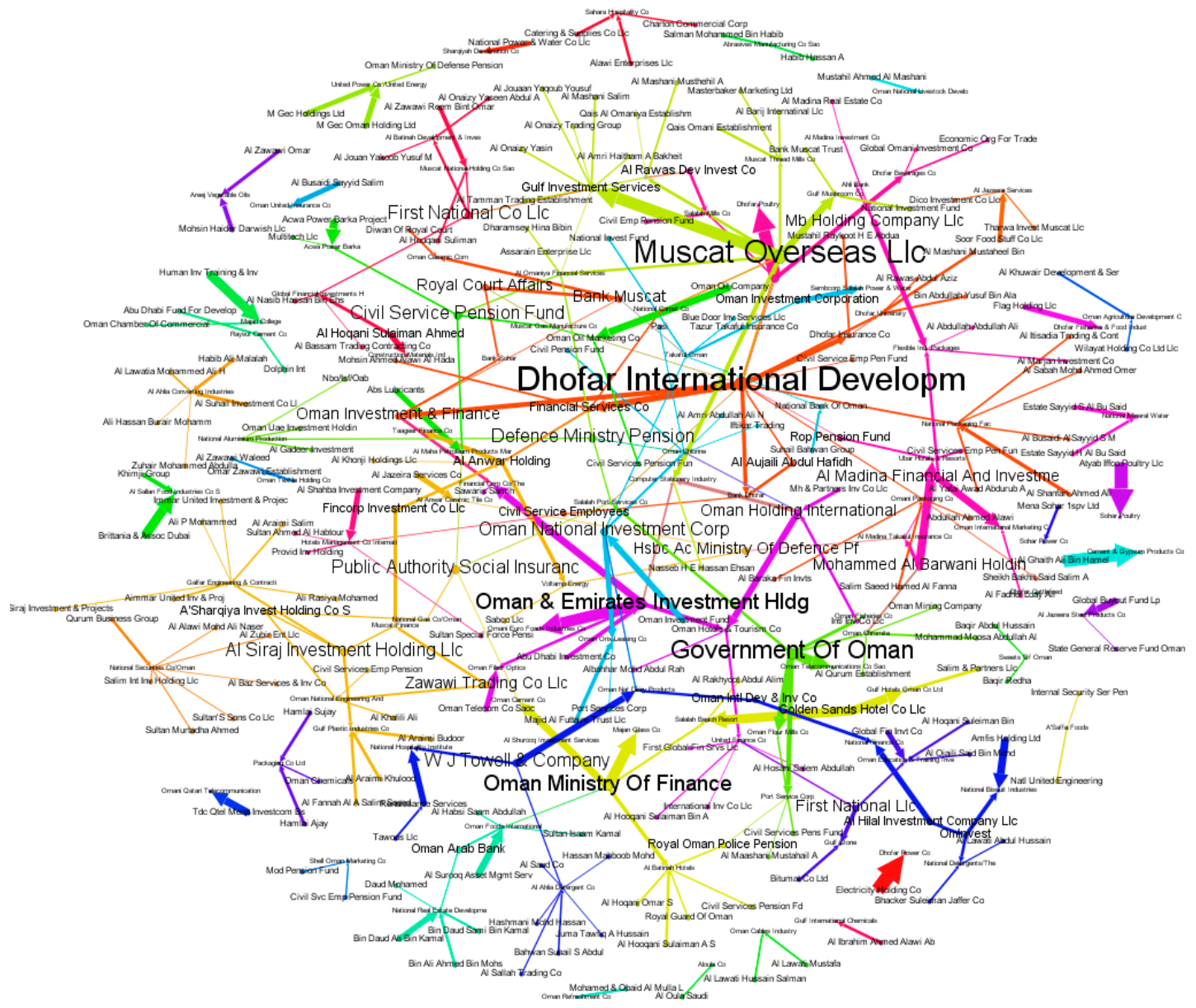

Source: Bloomberg, Muscat Securities Market, and staff calculations.

Figure 4. Qatar: Corporate Ownership Network

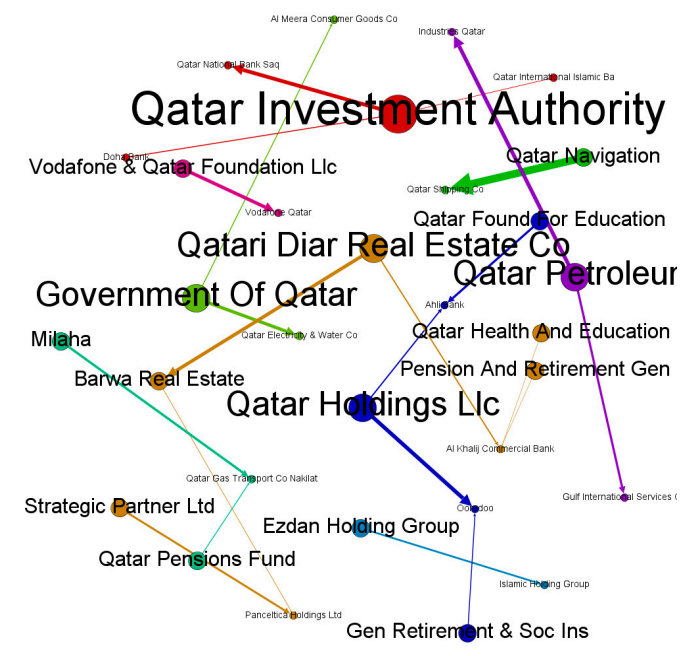

Source: Bloomberg, Qatar Stock Exchange, and staff calculations. 


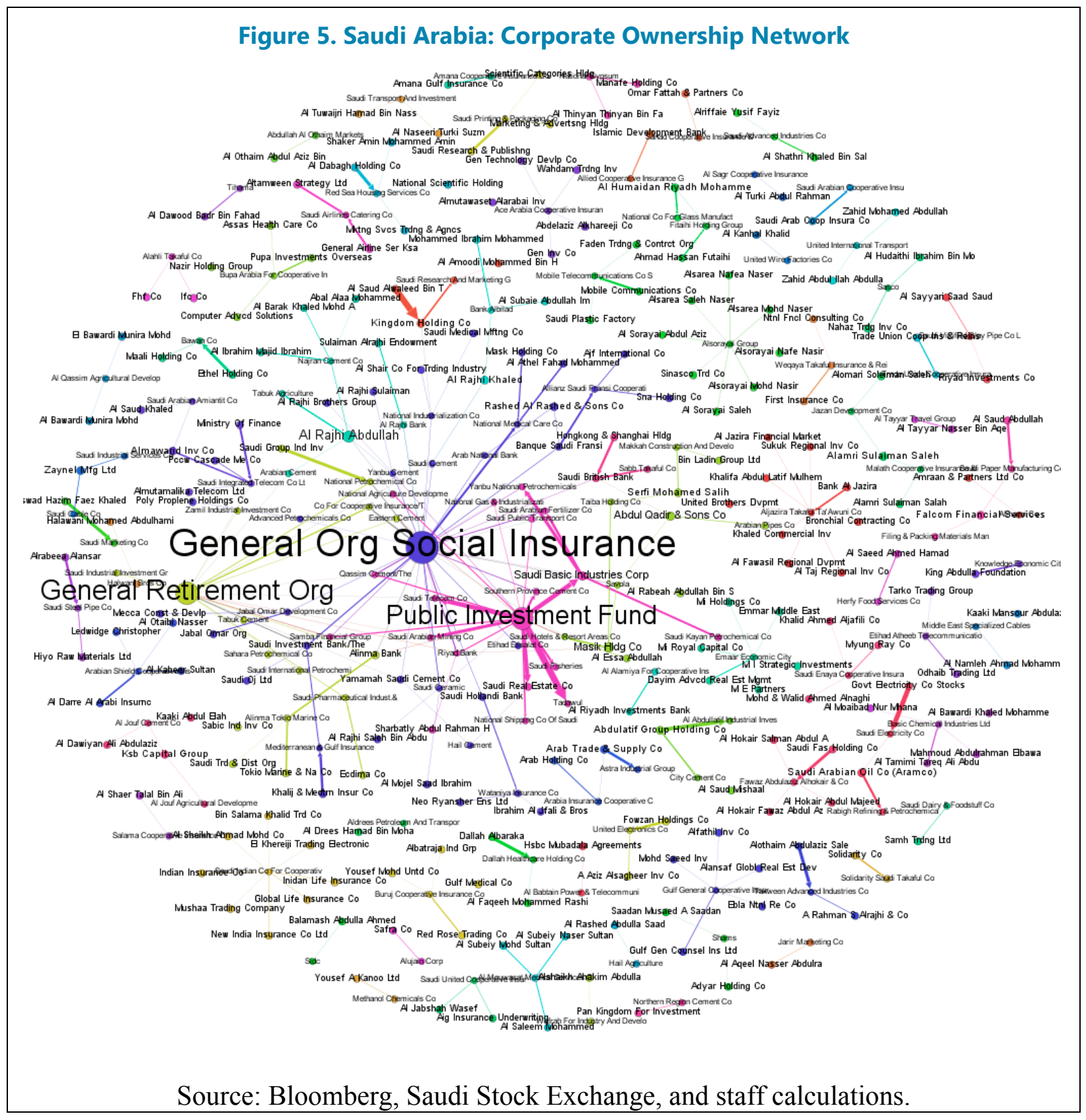




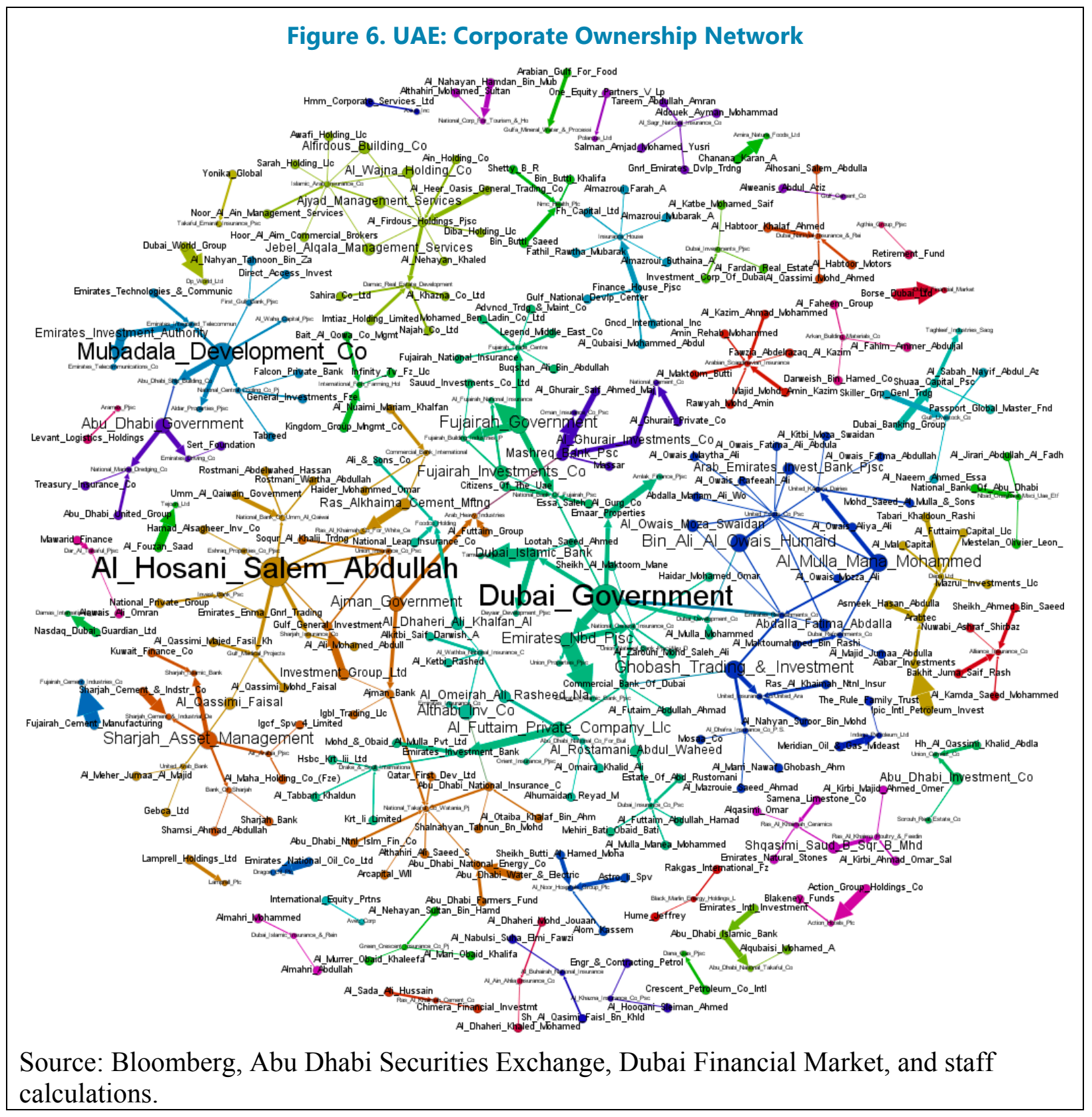


Figure 7. GCC: Concentration in Ownership Networks, End-2013

\section{Bahrain}

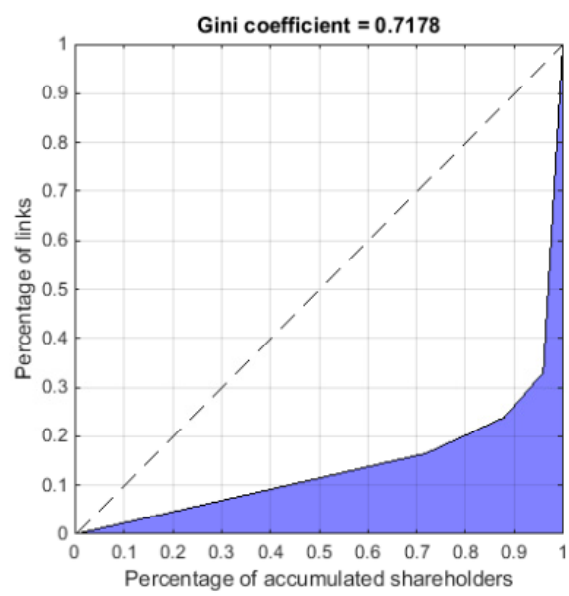

Oman

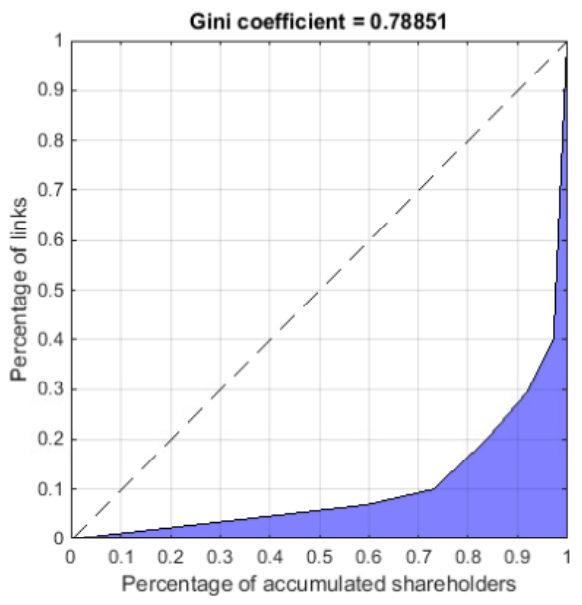

Saudi Arabia

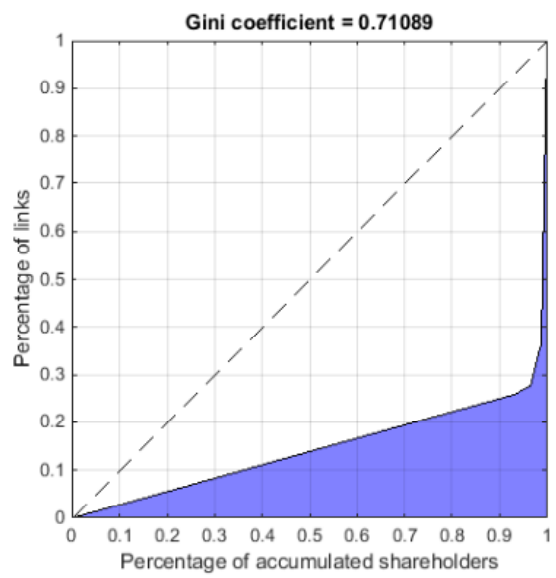

Kuwait

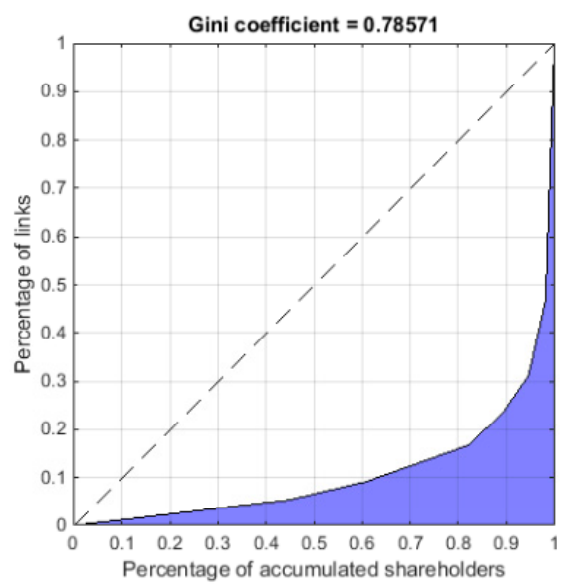

Qatar

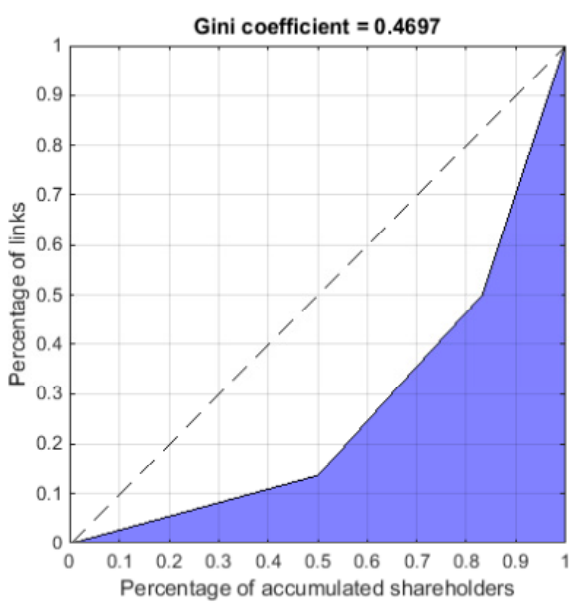

United Arab Emirates

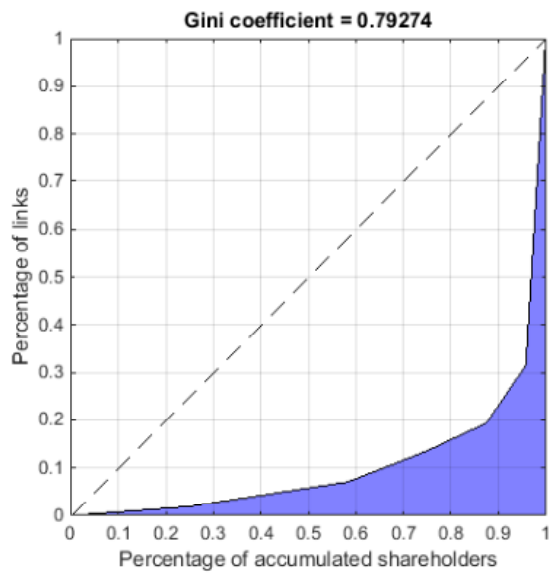

Sources: Bloomberg and staff calculations. 


\section{Control In The GCC CORPorate SECTOR}

Ownership data in publicly listed and privately owned GCC corporates also provide insights on control in the GCC corporate sector. Given the one-share-one-vote rule in the GCC countries, large ownership stakes are associated with the right to appoint board members and control firms. In addition, shareholders also exert control over corporates through indirect ownership links. Villalong and Amit (2008) indicate that dual-class stock, voting agreements, pyramids, and disproportional board representation can create a wedge between ownership and control. When there are pyramids, ultimate control is determined by the direct and indirect links in the ownership and control network. The effective control can be larger than the one implied by the direct links.

Ownership concentration has strong implications for corporate governance in GCC countries. Large controlling shareholders can appoint the majority of board members. OECD et al. (2009) reported that 54 percent of MENA banks do not have independent directors, implying that the appointment of independent non-executive directors with no association with controlling shareholders is not a common practice in MENA corporates. As a result, minority shareholders can be left unprotected with few independent non-executive directors safeguarding their interests, including monitoring conflicts of interest and related-party transactions. ${ }^{10}$ For instance, Aaltonen (2013) indicated that only 20 percent of the companies in the S\&P/Hawkamah Pan Arab ESG index, including publicly listed MENA corporates, conducted their related party transactions on market terms.

Given the close association between board members and controlling shareholders, board memberships provide one way in which corporates are connected as related parties. GCC board members surveyed in GCC Board of Directors Institute (2011) reported that nine percent of GCC board members sat on more than 4 boards. Given the average size of board members in the MENA region of 8.9 directors as according to Aaltonen (2013), close interlinks between corporates, banks, and public institutions can arise from related parties. ${ }^{11}$ As a result, board members holding managerial positions in the controlling shareholder institutions and other institutions with a direct interest by the controlling shareholder institutions give rise to a large network of related institutions, shareholders, and board members. Figures 1-6 help indentify related parties with common majority shareholders, especially those corporates with the sovereign as a major stakeholder.

\footnotetext{
${ }^{10}$ The board of directors plays an important role in the corporate governance of any company. It has the overall responsibility for the company, including the approval and oversight of its objectives, risk tolerance and management, internal controls system, corporate governance, and compensation system. It is also responsible for overseeing senior management. The board should exercise objective judgment independently of senior management, shareholders, and any other interest. A good practice is to appoint a large number of qualified, independent nonexecutive board members, which may also include board members representing minority shareholders.

${ }^{11}$ Indeed, the definition of related parties in the Basel core principles for effective banking supervision has incorporated not only entities that the bank exerts control but also entities that exert control over the bank, the bank's major shareholders, board members, senior management and key staff, their direct and related interests, and their close family members as well as corresponding persons in affiliated companies. The Basel core principles require banks to report and monitor any transactions with related parties.
} 
The new Basel standard on measuring and controlling large exposures has defined connected counterparties as a group of counterparties linked by a control relationship (either direct or indirect) or an economic interdependence. This definition is wide enough to include connected parties under different circumstances and both in the public and private sectors. In the case of connected counterparties, the exposures to all connected counterparties should be considered as a large single exposure for reporting and compliance purposes.

The Basel committee on banking supervision has recommended that banks report to supervisors the large exposures that are equal or above 10 percent of the capital base (Tier 1 capital), all the exemptions granted, and the 20 largest exposures irrespective of the value of these exposures relative to the capital base.

From a supervisory and regulatory perspective, bank exposures to connected counterparties arising from ownership and control links should be consolidated at the level of the controlling shareholders. Table 3 contains Herfindahl indices for connected counteparties' consolidated debt obtained under the four definitions of control detailed in section II.B: proportional to the shares in the integrated ownership for the largest shareholders (equation 6 in the section II.B) and at the level of the largest controlling shareholder with at least 5 percent of total shares (equation 7) as defined in Zingales (1994), with at least

\begin{tabular}{lccccc}
\multicolumn{5}{c}{ Table 3. GCC: Herfindahl Index for Debt Concentration, End-2013 } \\
\hline & $\begin{array}{c}\text { No } \\
\text { Consolidation }\end{array}$ & $\begin{array}{c}\text { Integrated } \\
\text { Ownership }\end{array}$ & $\begin{array}{c}\text { Zngales } \\
(1994)\end{array}$ & $\begin{array}{c}\text { La Porta et all } \\
(2002)\end{array}$ & $\begin{array}{c}\text { Modified Chapelle } \\
\text { and Szafarz } \\
(2002)\end{array}$ \\
\hline Bahrain & 0.1725 & 0.1297 & 0.1911 & 0.1888 & 0.1297 \\
Kuwait & 0.0769 & 0.1006 & 0.1235 & 0.1084 & 0.1019 \\
Oman & 0.1302 & 0.1485 & 0.1552 & 0.1351 & 0.1486 \\
Qatar & 0.1789 & 0.2027 & 0.2089 & 0.1981 & 0.2054 \\
Saudi Arabia & 0.0800 & 0.1447 & 0.1804 & 0.1646 & 0.1620 \\
UAE & 0.1126 & 0.1905 & 0.2007 & 0.1866 & 0.1905 \\
\hline
\end{tabular}
20 percent (equation 8) as in La Porta, Lopez-de-Silanes, and Sheleifer (1999), and with at least 50 percent (equation 9) as in Chapelle and Szafarz (2002). ${ }^{12,13}$ In this case, the Herfindahl index is a measure of debt concentration by borrowers, with values ranging from 0.15 to 0.25 and above 0.25 indicating moderate and high concentration, respectively. ${ }^{14}$ The debt amounts were based on information on long- and short-term debt disclosed in the 2013 annual reports and the total amount of syndicated loans and bonds also tracked by Bloomberg.

Debt concentration is the largest when control can be associated with low levels of ownership, as in the case under the Zingales (1994) definition of control. Two important conclusions can be drawn from Table 3. First, the Herfindahl index is larger for connected counterparties' consolidated debt than for non-consolidated corporate debt under any of the definitions of control, emphasizing the importance of consolidation. Second, the largest Herfindahl index is obtained under the Zingales (1994) definition of control as lower threshold levels imply more debt consolidation than higher threshold levels. Figure 8 plots

\footnotetext{
12 The Herfindahl index is a commonly used measure of market concentration. In the case of debt concentration, it is calculated by squaring the percentage of a borrower's debt in the total debt stock and then summing the resulting squared percentage over all borrowers.

${ }^{13}$ See previous section II.B for further details on the different definitions of control.

14 These thresholds are used by the U.S. Department of Justice to assess market competition and concentration associated with mergers and acquisitions.
} 
non-consolidated corporate and shareholder debt and the connected counterparties' consolidated debt under the Zingales (1994) definition of control. The debt distribution shifts to the right under the Zingales (1994) definition of control, implying a lower peak but a fatter tail than under the distribution generated by individual corporate debt. Therefore, there is a larger number of highly indebted borrowers under the Zingales (1994) definition of control.

Figure 8. GCC: Corporate Debt Distribution, End-2013

(In percent of GDP)

Bahrain
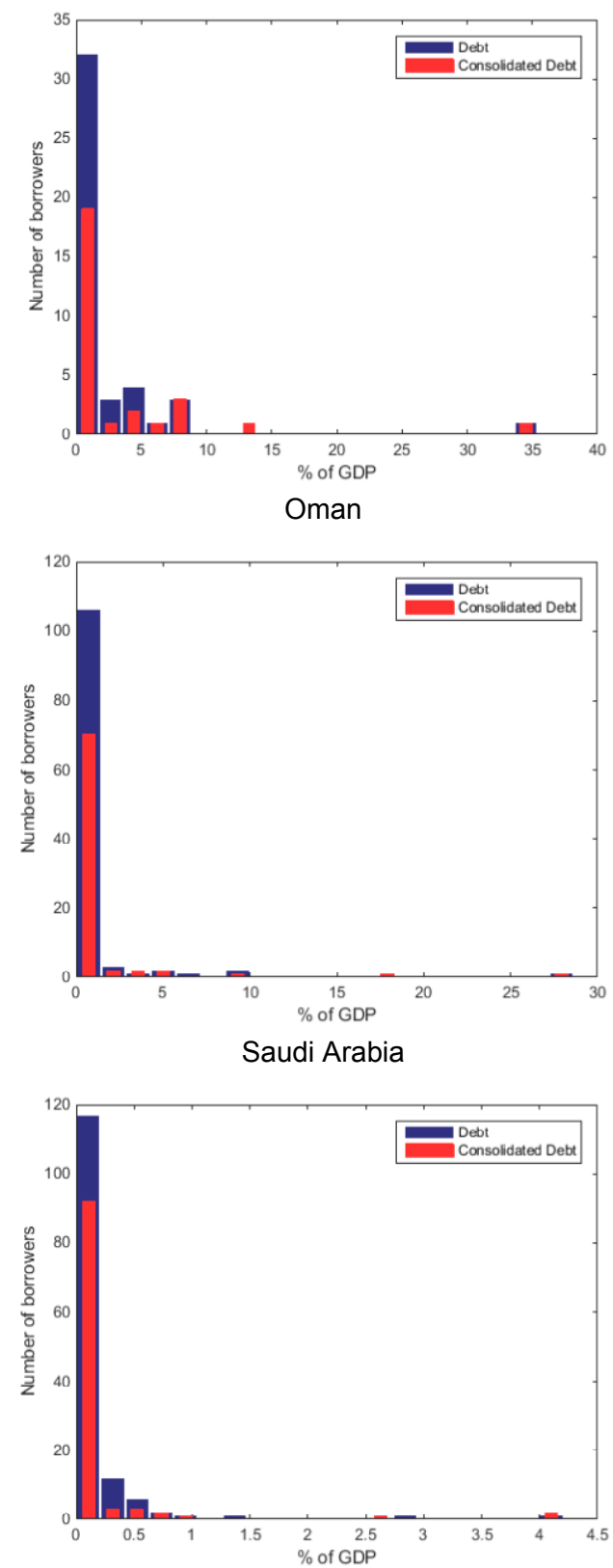

Kuwait
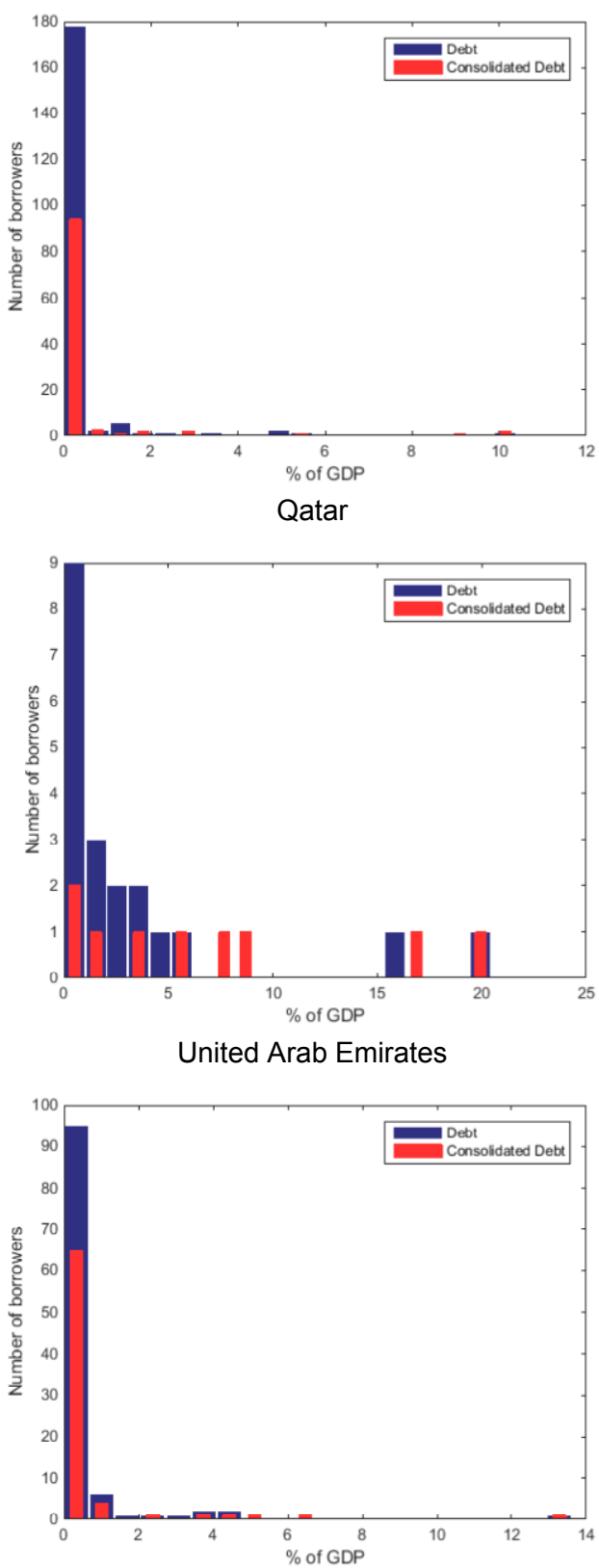

Source: Staff calculations. 


\section{Conclusion}

The paper assesses ownership and control links in GCC countries. The analysis focuses on the integrated ownership and network arising from ownership data available in Bloomberg and GCC stock exchanges. An ownership network is a system of links among shareholders and corporates that helps identify connected counterparties visually. The paper then analyzes the ownership concentration in GCC countries and identifies the key stakeholders.

However, the analysis of interconnectedness in the corporate sector based on information available in Bloomberg, GCC stock exchanges, and private sources has important caveats. First, the universe of total companies is limited as a large number of privately owned corporates with no disclosed ownership information is left unaccounted. Second, disclosed ownership information on publicly listed companies might not contain details on the ultimate shareholder. Finally, the links between corporates and shareholders rely on consistent records. The imprecise registration of shareholder and corporate add uncertainty to the network.

Integrated ownership in publicly listed GCC corporates by the ultimate shareholder is determined by both the direct and indirect ownership links. GCC shareholders can have large integrated ownership if indirect ownership at the corporate level is also taken into account. In this case, the effective ownership associated with the ultimate shareholder is larger than the one implied by the direct links and helps create a wedge between direct ownership and control in corporates.

Ownership in GCC countries is concentrated in public sector institutions, holding companies, financial institutions, and family groups. Public sector institutions have the highest number of ownership links and are at the center of the ownership networks. Holding companies, financial institutions, and family groups are also important shareholders with a high number of ownership links. Concentration in GCC countries is even higher than in most advanced and emerging countries.

The paper then identifies connected counterparties and their consolidated debt. The literature on corporate governance has defined share ownership thresholds associated with corporate control. The paper considers the effect of different definitions of control on the distribution of consolidated debt. Debt concentration is maximized when the wedge between ownership and control is the largest. This is the case when the largest controlling shareholder has at least 5 percent of total shares as in Zingales (1994).

The analysis in the paper is especially important in the context of the new Basel supervisory framework for measuring and controlling large exposures. The new Basel supervisory framework aims at limiting the maximum loss that a bank can incur in the event of a default of a large borrower or a group of connected counterparties. It has defined connected counterparties as a group of counterparties linked by a control relationship (either direct or indirect) or an economic interdependence. In this case, the exposures to all connected counterparties should be considered as a large single exposure for reporting and compliance purposes. 


\section{REFERENCES}

Aaltonen, A., 2013. Environmental, Social and Corporate Governance Practices in the MENA Region 2007-2012, (Dubai: Hawkamah The Institute for Corporate Governance).

Alves, P., 2008. "Who Owns the Largest Firms around the World?" MPRA Paper no. 52113. MPRA Paper no. 52355.

Alves, P., 2010. “Corporate Ownership: Some International Evidence,” MPRA Paper no. 51380.

Alves, P., 2012. “The Puzzle of Corporate Control,” MPRA Paper no. 52113.

Basel Committee on Banking Supervision, 2014, Supervisory Framework for Measuring and Controlling Large Exposures, (Basel: Bank of International Settlements).

Bastian, M., Heymann, S., and M. Jacomy, 2009. Gephi: An Open Source Software for Exploring and Manipulating Networks, International AAAI Conference on Weblogs and Social Media.

Brioschi, F., L. Buzzacchi, and M. Colombo, 1989. "Risk Capital Financing and the Separation of Ownership and Control in Business Groups," Journal of Banking and Finance, Vol. 13, pp. 747-772.

Chappelle, A. and A. Szafar, 2002. "Ownership and Control: Dissecting the Pyramid," Centre Emile Bernheim Working Paper no. 03/002 (Brussels: Unveristé Libre de Bruxelles).

Chappelle, A. and A. Szafar, 2005. "Controlling Firms through the Majority Voting Rule," DULBEA Working Paper no. 05-05.RS (Brussels: Unveristé Libre de Bruxelles).

Ellerman, D., 1991. “Cross Owership of Corporations: A new Application of Input-Output Theory," Metroeconomics, Vol. 42(1), pp. 33-46.

GCC Board of Directors Institute, 2011, Embarking on a Journey: A Review of Board Effectiveness in the Gulf, (Dubai: GCC Board of Directors Institute).

Glattfelder, J. B., 2013. Decoding Complexity, chapter 3 (Berling: Springer-Verlag).

Gutiérrez, L., C. Pombo, and R. Taborda, 2005. "Ownership and Control in Colombian Corporations," IDB Research Network Working Paper no. R-520 (Washington: InterAmerican Development Bank).

Gutiérrez, L., C. Pombo, 2007. "Corporate Governance and Firm Valuation in Colombia," IDB Working Paper no. 568 (Washington: Inter-American Development Bank). 
International Monetary Fund, 2014. Annual Report on Exchange Arrangements and Exchange Restrictions, (Washington: International Monetary Fund).

International Monetary Fund, 2014. "Assessing Concentration in GCC Banks," GCC Background Papers (Washington: International Monetary Fund).

La Porta, R., F. Lopez-de-Silanes, and A. Sheleifer, 1999, "Corporate Ownership around the World," Journal of Finance, Vo. LIV(2), pp. 471-517.

Kingdom of Saudi Arabia Capital Market Authority, 2015. Rule for Qualified Foreign Financial Institutions Investment in Listed Shares, (Riyadh: Kingdom of Saudi Arabia Capital Market Authority).

Kogut, B. and G. Walker, 2001. "The Small World of Germany and the Durability of National Networks," American Sociological Review, Vol. 66, pp. 317-35.

Krackhardt, D, 1994. "Graph Theoretical Dimension of Informal Organizations" in Carley, K. and M. Prietula (eds), Computational Organizational Theory (Hillsdale, NJ: Lawrence Erbaum Associates), pp. 89-111.

Kunegis, J. and Julia Preusse, 2012. "Fairness on the Web: Alternatives to the Power Law," WebSci, June.

OECD, Hawkamah-The Global Corporate Governance Forum, and Union of Arab Banks, 2009. Policy Brief on Improving Corporate Governance of Banks in the Middle East and North Africa Region, (Paris: OECD).

Rotundo, G. and A. M. D’Arcangelis, 2010. “Ownership and Control in Shareholding Netwoks, Journal of Economic Interaction and Coordination, Vol. 5, pp. 191-219.

Villalonga, B. and R. Amit, 2008. "How are U.S. Family Firms Controlled?" Review of Financial Studies, Vol. 22(8), pp. 3047-91. 